Ophthalmologica

\title{
Large Subretinal Haemorrhage following Change from Intravitreal Bevacizumab to Ranibizumab
}

\author{
Dimitrios A. Karagiannis ${ }^{a}$ Panagiotis Mitropoulos ${ }^{a}$ Ioannis D. Ladas ${ }^{b}$ \\ a Second Department of Ophthalmiatrio, Eye Hospital of Athens, and ${ }^{b}$ First Department of Ophthalmology, \\ Medical School of Athens University, Athens, Greece
}

\section{Key Words}

Age-related macular degeneration - Bevacizumab •

Ranibizumab $\cdot$ Subretinal haemorrhage

\begin{abstract}
Background: To report 2 cases of large subretinal haemorrhage in 2 patients with age-related macular degeneration when the intravitreal injections were changed from bevacizumab (Avastin) to ranibizumab (Lucentis). Methods: Both patients were treated initially with intravitreal bevacizumab $1.25 \mathrm{mg}$ for 4 months ( 4 injections) and then switched to 0.5 mg ranibizumab which continued for another 6 months. Best-corrected visual acuity measurements, slit-lamp examination, contact lens biomicroscopy, optical coherence tomography and fluorescein angiography were performed at baseline examination and every month. Results: Both patients showed initial improvement when treated with intravitreal bevacizumab followed by deterioration and development of a large subretinal haemorrhage when changing to intravitreal ranibizumab. Conclusions: There is not enough experience switching from one anti-vascular-endothelialgrowth-factor agent to another. A prospective study with large series of patients and controls may be necessary in order to determine whether it is safe enough to change from one medication to another.

Copyright $\odot 2009$ S. Karger AG, Basel
\end{abstract}

\section{Introduction}

Age-related macular degeneration (AMD) is the most common cause of visual loss in patients over 65 years of age [1]. Recently, many agents that suppress the action of vascular endothelial growth factor (VEGF) have been used for the treatment of choroidal neovascularization in patients with AMD. Ranibizumab (Lucentis) is a fully humanized anti-VEGF antibody fragment that binds to all isoforms of VEGF [2]. Bevacizumab (Avastin) is a recombinant humanized full-length antibody that binds to all isoforms of VEGF, similar to ranibizumab. For the last 2 years, it has been offered as an off-label intravitreal application for the treatment of wet AMD [3-5].

We report 2 patients with AMD who developed large subretinal haemorrhage when the intravitreal injections were changed from bevacizumab to ranibizumab.

\section{Case Report}

Two patients were treated initially with intravitreal bevacizumab $1.25 \mathrm{mg} / 0.05 \mathrm{ml}$ for 4 months (4 injections) and then switched to $0.5 \mathrm{mg}$ ranibizumab for another 6 months. No systemic side effects were noted.

Although there was initial improvement following bevacizumab injections, both patients insisted to change to ranibizum$\mathrm{ab}$ when the latter became commercially available in our country.

\section{KARGER}

Fax +4161306 1234 E-Mail karger@karger.ch www.karger.com
(C) 2009 S. Karger AG, Basel

$0030-3755 / 09 / 2234-0279 \$ 26.00 / 0$

Accessible online at:

www.karger.com/oph
Dimitrios A. Karagiannis

15 Ariadnis Street

GR-14563 Kifissia (Greece)

Tel. +30 6945973800 , Fax +30 2103235526

E-Mail dimitrioskaragiannis@doctors.org.uk 
Fig. 1. a Late phase of FFA of the LE of the first patient at initial presentation showing exudative AMD. $\mathbf{b}$ Late phase of FFA of the same patient after 4 injections of bevacizumab showing improvement and less leakage of the dye. c Venous phase of FFA of the same patient after the first injection of ranibizumab showing the active lesion and an area of hypofluorescence superotemporal to the lesion corresponding to the subretinal haemorrhage. d After the third injection of ranibizumab, the subretinal haemorrhage had expanded and started spreading into the vitreous cavity. One month later, funduscopy was impossible due to vitreous haemorrhage.
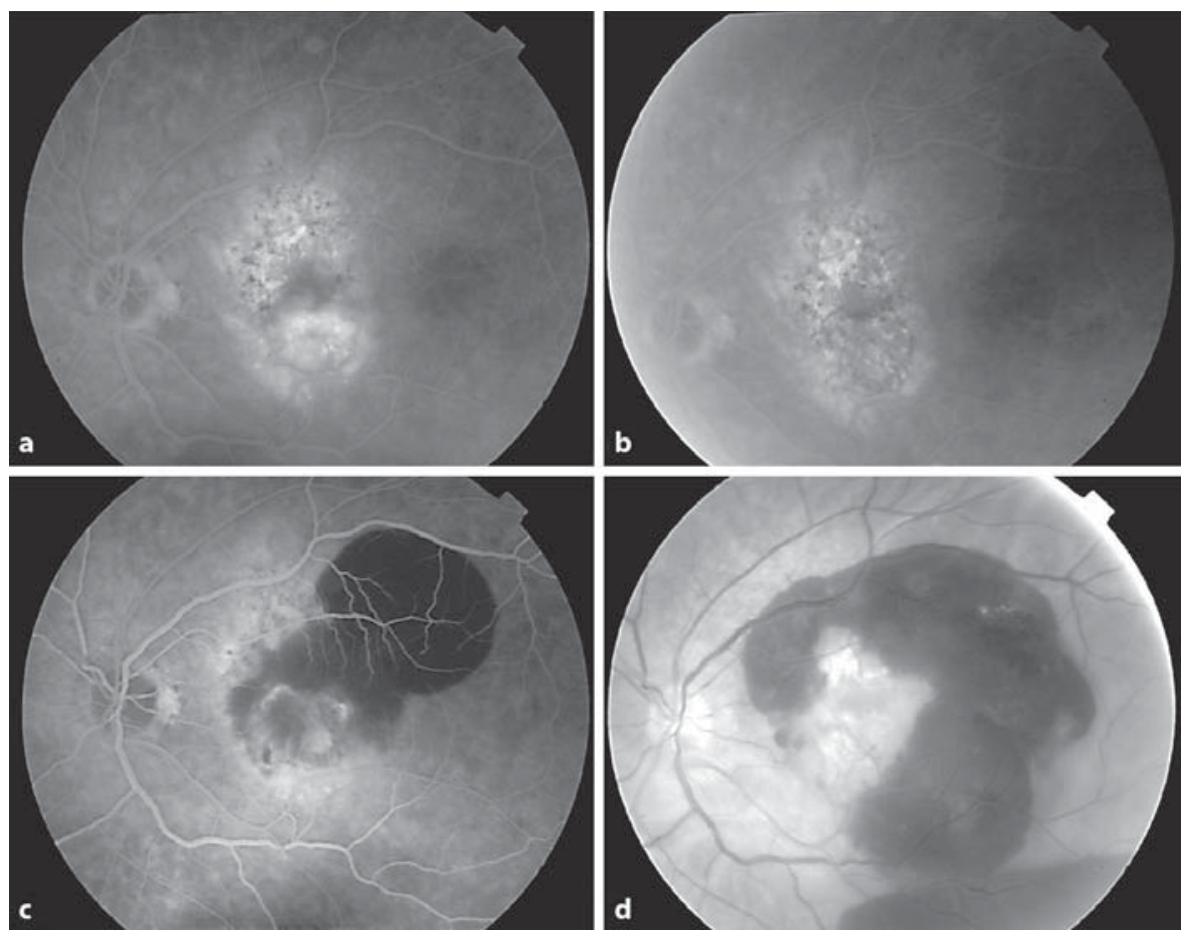

Best-corrected visual acuity measurements (BCVA), slit-lamp examination, contact lens biomicroscopy, optical coherence tomography (OCT) and fundus fluorescein angiography (FFA) were performed at baseline examination and on a monthly basis. Both patients were not under aspirin treatment.

The first patient was a 78-year-old Caucasian male who complained of 2 months' deterioration in vision in his left eye. On presentation, his BCVA was $1 / 10$ in the left eye (LE) and 1/20 in the right (RE). Clinical examination, FFA and OCT showed the presence of wet AMD in his LE and a macular scar in the RE. After explained risks and benefits the patient was started on intravitreal bevacizumab (fig. 1a). After 4 monthly injections, his BCVA improved to 5/10 (fig. 1b). One month after the last bevacizumab injection, the patient underwent the first injection of ranibizumab and presented at his follow-up appointment (3 weeks postoperatively) with large subretinal haemorrhage (fig. 1c). In spite of the fact that ranibizumab treatment was continued on a monthly basis, haemorrhage expanded into the vitreous cavity, and his vision decreased to hand movements (fig. 1d).

The second patient was a 72-year-old Caucasian male who complained of 3 months' deterioration in vision in the LE. On presentation, his BCVA was $1 / 10$ in the LE and 10/10 in the RE. FFA and OCT confirmed the presence of wet AMD in the LE, and he was started on intravitreal bevacizumab. The right macula was healthy. Injections were performed every month, and after 4 injections of bevacizumab his BCVA improved to $3 / 10$; however, the disease was still active (fig. $2 \mathrm{a}, \mathrm{b}$ ). One month later, the patient underwent the first injection of ranibizumab, and 3 weeks postoperatively he developed a large subretinal haemorrhage tempo- ral to the fovea (fig. 2c). Within the next 4 months, the haemorrhage expanded further (fig. 2d) although intravitreal injections of ranibizumab had been continued every month. His BCVA decreased to $1 / 20$ (fig. $2 c, d$ ).

\section{Discussion}

AMD is the most common cause of visual loss in patients over 65 years of age [1]. Two-year results of the MARINA study showed that patients with minimally classic or occult choroidal neovascularization, treated with intravitreal injections of ranibizumab, gained on average 7 letters in BCVA after 12 months, and they maintained this functional benefit after 24 months [6]. Many other reports support these favourable results of ranibizumab [7-9]. In addition, bevacizumab showed very promising results as an off-label treatment for wet AMD [3-5].

According to the literature, complications such as retinal epithelial tears are known [10]. In both our cases, OCT covered the whole macular area which did not show any signs of retinal tear which could result in such a haemorrhage. It is known that the natural history and the visual outcome of a submacular haemorrhage in AMD 
Fig. 2. a Colour fundus picture of the LE of the second patient at the initial presentation. $\mathbf{b}$ Late phase of FFA of the LE of the second patient showing active wet AMD. c Late phase of FFA of the same patient after the first injection of ranibizumab showing the hypofluorescence corresponding to haemorrhage, temporal to the fovea. d Late phase of FFA of the same patient, 3 months later, showing the hypofluorescence corresponding to haemorrhage. The haemorrhage has expanded further.
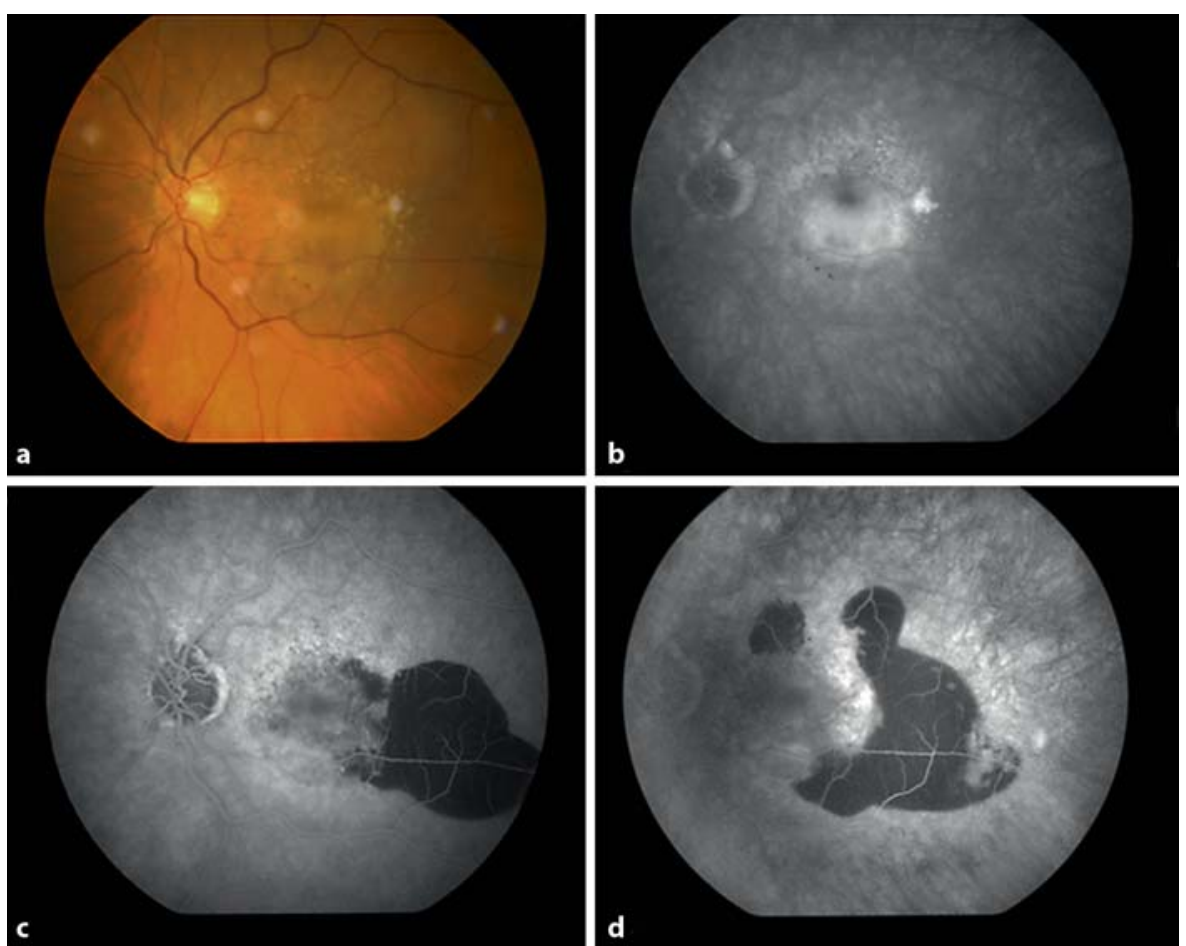

are very poor [11]. However, Stifter et al. [12] reported that intravitreal bevacizumab seems to be a promising therapeutic option in eyes with neovascular AMD and large submacular haemorrhages, with a stabilization in BCVA and anatomic improvement. Although treatment was continued on a monthly basis, both our patients deteriorated further.

Both our patients showed initial improvement by intravitreal injections of bevacizumab followed by immediate deterioration when their medication was changed to ranibizumab. In both cases, ranibizumab injections were performed 1 month after the last bevacizumab injection. It is known that both medications have good visual and anatomical outcome alone; however, the molecular size of ranibizumab is half that of bevacizumab and the halflife in the vitreous is different [13]. In addition, the higher affinity and thus stronger initial effects of ranibizumab which rapidly penetrates through the retina to reach the choroid may be responsible for the severe side effects [14]. There is no such experience changing from one antiVEGF agent to another. It is difficult to justify this deterioration in both cases and to determine whether it is related to the natural course of the disease or to the change of medication. However, we postulate that the change of treatment from a larger molecule such as bevacizumab to a half-size molecule with a shorter half-life in the vitreous such as ranibizumab with higher penetration into the retina contributed to the large haemorrhage. A prospective study with large series of patients and controls may be necessary in order to determine whether it is safe enough to change from one medication to another.

\footnotetext{
References $D_{1}$ Ambati J, Ambati BK, Yoo SH, Ianchulev S, Adamis AP: Age-related macular degeneration: etiology, pathogenesis, and therapeutic strategies. Surv Ophthalmol 2003;48:257293.

-2 Brown DM, Kaiser PK, Michels M, Soubrane G, Heier JS, Kim RY, Sy JP, Schneider S, ANCHOR Study Group: Ranibizumab versus verteporfin for neovascular age-related macular degeneration. N Engl J Med 2006;355: 1432-1444

- 3 Avery RL, Pieramici DJ, Rabena MD, Castellarin AA, Nasir MA, Giust MJ: Intravitreal bevacizumab (Avastin) for neovascular agerelated macular degeneration. Ophthalmology 2006;113:363-372.
} 
4 Rich RM, Rosenfeld PJ, Puliafito CA, Dubovy SR, Davis JL, Flynn HW Jr, Gonzales S, Feuer WJ, Lin GA, Laiwani GA, Nguyen JK, Kumar G: Short-term safety and efficacy of intravitreal bevacizumab (Avastin) for neovascular age-related macular degeneration. Retina 2006;26:495-511.

5 Bashshur ZF, Haddad ZA, Schakal A, Jaafar RF, Saab M, Noureddin BN: Intravitreal bevacizumab for treatment of neovascular agerelated macular degeneration: a one-year prospective study. Am J Ophthalmol 2008; 145:249-256.

6 6 Rosenfeld PJ, Brown DM, Heier JS, Boyer DS, Kaiser PK, Chung CY, Kim RY, MARINA Study Group: Ranibizumab for neovascular age-related macular degeneration. N Engl J Med 2006;355:1419-1431.
Regillo CD, Brown DM, Abraham P, Yue H, Ianchulev T, Schneider S, Shams N, PIER Study Group: Randomized, double-masked, sham-controlled trial of ranibizumab for neovascular age-related macular degeneration: PIER study year 1. Am J Ophthalmol 2008;145:239-248.

8 Chang TS, Bressler NM, Fine JT, Dolan CM, Ward J, Klesert TR, MARINA Study Group: Improved vision-related function after ranibizumab treatment of neovascular age-related macular degeneration: results of a randomized clinical trial. Arch Ophthalmol 2007;125:1460-1469.

$\checkmark 9$ Bhatnagar P, Spaide RF, Takahashi BS, Peragallo JH, Freund KB, Klancnik JM, Cooney MJ, Slakter JS, Sorenson JA, Yannuzzi LA Ranibizumab for treatment of choroidal neovascularization secondary to age-related macular degeneration. Retina 2007;27:846850.

10 Bakri SJ, Kitzmann AS: Retinal epithelial tear after intravitreal ranibizumab. Am J Ophthalmol 2007;143:505-507.
1 Scupola A, Coscas G, Soubrane G, Balestrazzi E: Natural history of macular subretinal hemorrhage in age-related macular degeneration. Ophthalmologica 1999;213: 97-102.

12 Stifter E, Michels S, Prager F, Georgopoulos M, Polak K, Hirn C, Schmidt-Erfurth U: Intravitreal bevacizumab therapy for neovascular age-related macular degeneration with large submacular hemorrhage. Am J Ophthalmol 2007;144:886-892.

13 Bakri SJ, Snyder MR, Reid JM, Pulido JS, Ezzat MK, Singh RJ: Pharmacokinetics of intravitreal ranibizumab (Lucentis). Ophthalmology 2007;114:2179-2182.

14 Gaudreault J, Fei D, Beyer JC, Ryan A, Rangell L, Shiu V, Damico LA: Pharmakokinetics and retinal distribution of ranibizumab, a humanized antibody fragment directed against VEGF-A, following intravitreal administration in rabbits. Retina 2007;27: 1260-1266. 